\title{
On the Applicability of Chitosan Oligomers-Amino Acid Conjugate Complexes as Eco-Friendly Fungicides against Grapevine Trunk Pathogens
}

\author{
Laura Buzón-Durán ${ }^{1}\left(\mathbb{D}\right.$, Natalia Langa-Lomba ${ }^{2,3}{ }^{\circledR}$, Vicente González-García ${ }^{3}{ }^{\circledR}$, José Casanova-Gascón ${ }^{2, *}{ }^{\circledR}$, \\ Jesús Martín-Gil ${ }^{1}{ }^{\mathbb{D}}$, Eduardo Pérez-Lebeña ${ }^{1}$ and Pablo Martín-Ramos ${ }^{2} \mathbb{C}$ \\ 1 Department of Agricultural and Forestry Engineering, ETSIIAA, Universidad de Valladolid, \\ 34004 Palencia, Spain; laura.buzon@uva.es (L.B.-D.); mgil@iaf.uva.es (J.M.-G.); eplebena@gmail.com (E.P.-L.) \\ 2 Instituto Universitario de Investigación en Ciencias Ambientales de Aragón (IUCA), EPS, \\ Universidad de Zaragoza, Carretera de Cuarte, s/n, 22071 Huesca, Spain; \\ natalialangalomba@gmail.com (N.L.-L.); pmr@unizar.es (P.M.-R.) \\ 3 Plant Protection Unit, Agrifood Research and Technology Centre of Aragón, \\ Instituto Agroalimentario de Aragón-IA2 (CITA-Universidad de Zaragoza), Avda. Montañana 930, \\ 50059 Zaragoza, Spain; vgonzalezg@aragon.es \\ * Correspondence: jcasan@unizar.es; Tel.: +34-974239339
}

\section{check for}

updates

Citation: Buzón-Durán, L.; Langa-Lomba, N.; González-García,

V.; Casanova-Gascón, J.; Martín-Gil, J.; Pérez-Lebeña, E.; Martín-Ramos, P. On the Applicability of Chitosan Oligomers-Amino Acid Conjugate Complexes as Eco-Friendly Fungicides against Grapevine Trunk Pathogens. Agronomy 2021, 11, 324. https://doi.org/10.3390/ agronomy11020324

Academic Editor: Thorsten Kraska Received: 29 December 2020

Accepted: 7 February 2021

Published: 12 February 2021

Publisher's Note: MDPI stays neutra with regard to jurisdictional claims in published maps and institutional affiliations.

Copyright: (C) 2021 by the authors Licensee MDPI, Basel, Switzerland. This article is an open access article distributed under the terms and conditions of the Creative Commons Attribution (CC BY) license (https:// creativecommons.org/licenses/by/ $4.0 /)$.
Abstract: In a context in which the incidence and severity of grapevine fungal diseases is increasing as a result of both climate change and modern management culture practices, reducing the excessive use of phytosanitary products in viticulture represents a major challenge. Specifically, grapevine trunk diseases (GTDs), caused by several complexes of wood decay or xylem-inhabiting fungi, pose a major challenge to vineyard sustainability. In this study, the efficacy of chitosan oligomers (COS)-amino acid conjugate complexes against three fungal species belonging to the Botryosphaeriaceae family (Neofusicoccum parvum, Diplodia seriata, and Botryosphaeria dothidea) was investigated both in vitro and in planta. In vitro tests led to $\mathrm{EC}_{50}$ and $\mathrm{EC}_{90}$ effective concentrations in the 254.6-448.5 and $672.1-1498.5 \mu \mathrm{g} \cdot \mathrm{mL}^{-1}$ range, respectively, depending on the amino acid involved in the conjugate complex (viz. cysteine, glycine, proline or tyrosine) and on the pathogen assayed. A synergistic effect between COS and the amino acids was observed against $D$. seriata and B. dothidea (synergy factors of up to 2.5 and 2.8, respectively, according to Wadley's method). The formulations based on COS and on the conjugate complex that showed the best inhibition rates, COS-tyrosine, were further investigated in a greenhouse trial on grafted vines of two varieties ("Tempranillo" on 775P and "Garnacha" on 110R rootstock), artificially inoculated with the mentioned three Botryosphaeriaceae species. The in planta bioassay revealed that the chosen formulations induced a significant decrease in disease severity against $N$. parvum and B. dothidea. In summary, the reported conjugate complexes may be promising enough to be worthy of additional examination in larger field trials.

Keywords: Botryosphaeriaceae; chitosan; fungicide; GTD; IPM; tyrosine; Vitis vinifera

\section{Introduction}

The so-called grapevine trunk diseases (GTDs) represent one of the greatest threats to vineyards in the last 20-25 years, as a consequence of changes in the management and intensification of the crop, the increase in the production of propagating plant material, the banning of chemicals or the existence of a climate change scenario. The International Organization of Vine and Wine (OIV) has estimated that the incidence rate of GTDs is approximately 10, 13 and 13.5\% of Spanish, French and Italian vineyards, respectively [1]. At a global level, economic losses caused by GTDs exceed US\$1.5 billion/year [2].

Among these, ascomycetous taxa belonging to the family Botryosphaeriaceae are responsible for large losses due to their incidence, especially in young grapevine plants coming 
from nurseries. Pathogenicity studies have shown that grapevine-associated species belonging to the genera Botryosphaeria, Lasiodiplodia and Neofusicoccum are among the fastest colonizing wood fungi and are therefore considered the most virulent cause of wood diseases [3]. External symptoms produced by this pathogenic complex include death of the cordons, canes, shoots and buds, stunting, bud necrosis, bleached canes, reduced bunch set and bunch rots, while internal symptoms like brown wood streaking and wedge-shaped discolorations are very frequent $[4,5]$. Together with these disease symptoms, these and other related GTD fungi are known to produce toxic metabolites [6], some of them well characterized by chemical methods, whose toxicity has been proven on different organs and tissues of several Vitis vinifera L. cultivars [7].

A comprehensive overview of the current state-of-the-art concerning chemicals (including inorganic, synthetic organic, natural, and elicitor compounds), biocontrol agents (BCAs) or preventive and post-infection management practices that have been examined against GTDs may be found in the review papers by Vincenzo, et al. [8], Gramaje, UrbezTorres and Sosnowski [3] and Mondello, Songy, Battiston, Pinto, Coppin, Trotel-Aziz, Clement, Mugnai and Fontaine [1]. However, it is necessary to clarify that at present there are no last-generation chemical methods or alternative treatments with proven efficacy [9], which explains why preventive cultural measures are generally used [10].

In order to comply with the European legislation currently in force (Article 14 in European Directive 2009/128/EC), the implementation of integrated pest management (IPM) methods has become a priority objective in plant disease control worldwide. The efforts oriented towards the selection and/or development of rootstocks and varieties with certain levels of tolerance against different trunk mycoses have not been successful to date [11-16], and the use of strategies involving endophytic microorganisms as microbial antagonists (BCAs) obtains a certain degree of protection, but no single BCA application has been able to control GTDs at similar rates to those shown by chemical fungicides, which are now banned [17]. Hence, other alternative/complementary strategies have to be explored and improved, such as the application of substances of natural origin that are safe, effective and sustainable from an environmental point of view [18].

As regards this latter option, polysaccharide-amino acid conjugates are drawing much attention due to their biocompatibility, design flexibility, adjustable degradability, and similarity-in terms of structure - to natural glycoproteins [19].

It is worth noting that plant host defense peptides (HDPs) or antimicrobial peptides (AMPs), generally cysteine-rich (nodule-specific cysteine-rich peptides, NCRs), are considered one of the main barriers developed by plants to fight infective agents [20-22], and are now being studied as antimicrobial agents against drug-resistant bacteria and other biomedical applications $[23,24]$. Amongst the different types of HDPs, the Snakin class is particularly interesting, as it encompasses the principal cysteine-rich peptides and given that the Snakin/GASA gene family has been identified in the grapevine [25]. As noted by Álvarez, et al. [26], cysteine is a keystone metabolite in the immune response pathways of plants, functioning as a precursor for many defense compounds (for example, phytoalexins, thionins, glucosinolates, etc.), and is associated with high resistance rates to both bio- and necrotrophic phytopathogens. In a recent study by Roblin, et al. [27], it was reported that cysteine may be able to control fungal diseases either by acting directly on fungal development and/or functioning as an early signal that elicits the plant's host reaction. In relation to GTDs, the same group also chose cysteine as a one of the chemicals in their experimental model aimed at the elaboration of preventive and/or curative treatments of esca syndrome [28].

Regarding polysaccharides, chitosan, a well-known compound with proven control properties, has been assayed against GTDs in different formulations: e.g., chitosan oligomers can protect pruning wounds inoculated with Phaeomoniella chlamydospora (W. Gams, Crous, M.J. Wingf. \& Mugnai) Crous \& W. Gams and Diplodia seriata de Not. in field trials [29]; high molecular weight chitosan reduced mycelial growth of Botryosphaeria sp., Phomopsis sp., Eutypa lata (Pers.) Tul. \& C. Tul., Neonectria liriodendri Halleen, Rego \& Crous, 2006, P. chlamydospora 
and Fomitiporia sp. [30]; oleoyl-chitosan nanoparticles reduced the mycelium growth of Botryosphaeria dothidea (Moug. ex Fr.) Ces. \& De Not. [31]; chitosan oligomers/propolis/silver nanoparticles composites have been tested against $D$. seriata [32]; and $\varepsilon$-polylysine:chitosan oligomers conjugates showed antifungal activity against Neofusicoccum parvum (Pennycook \& Samuels) Crous, Slippers \& A.J.L. Phillips, Diplodia seriata, and B. dothidea [33].

In connection with polysaccharide-amino acid conjugates, several examples for medical applications have been recently reported [34-36], but applications in the field of agronomy are still at a very early stage of development. To the best of the authors' knowledge, there is only one recent study on chitosan oligomers-amino acid conjugates against Fusarium culmorum (Wm.G. Sm.) Sacc., in spelt (Triticum spelta L.) by some of the co-authors of this work [37].

The aim of this study was to assess both the in vitro and in vivo antifungal efficacy of chitosan oligomers and amino acid conjugate complexes to control three of the most prevalent fungal pathogens associated with GTDs, especially in young plants: N. parvum, D. seriata, and B. dothidea.

\section{Materials and Methods}

\subsection{Fungal Isolates}

The three fungal isolates under study, viz. N. parvum (ITACYL_F111), D. seriata (ITACYL_F079) and B. dothidea (ITACYL_F141), were all isolated from diseased grapevine plants from D.O. Ribera de Duero and supplied as lyophilized vials (later reconstituted and refreshed as PDA subcultures) by the Agricultural Technological Institute of Castilla and Leon (ITACYL, Valladolid, Spain) [38].

\subsection{Reagents and Preparation of Chitosan Oligomers and Bioactive Formulations}

Chitosan (CAS 9012-76-4; high MW: 310,000-375,000 Da) was supplied by Hangzhou Simit Chem. \& Tech. Co. (Hangzhou, China). The four amino acids (cysteine, CAS 52-90-4; glycine, CAS 56-40-6; proline, CAS 147-75-3; and tyrosine, CAS 60-8-4) were purchased from Panreac (Barcelona, Spain). Citric acid (CAS 77-92-9), sodium alginate (CAS 9005-383) and calcium carbonate (CAS 471-34-1) were purchased from Sigma-Aldrich Química (Madrid, Spain). Neutrase ${ }^{\mathrm{TM}} 0.8 \mathrm{~L}$ enzyme was supplied by Novozymes A/S (Bagsværd, Denmark). Potato dextrose agar (PDA) was purchased from Becton Dickinson (Bergen County, NJ, USA).

Chitosan oligomers (COS) were prepared according to the procedure previously reported in [33]. Cysteine (Cys), glycine (Gly), proline (Pro) and tyrosine (Tyr) solutions were obtained by dissolution of the amino acids (with $99 \%$ purity) in sterile double distilled water at an initial concentration of $3000 \mu \mathrm{g} \cdot \mathrm{mL}^{-1}$. The COS-amino acid conjugate complexes were obtained by mixing of the respective solutions in a 1:1 $(v / v)$ ratio. The mixture was then sonicated for $15 \mathrm{~min}$ in five 3-min periods (so that the temperature did not exceed $60^{\circ} \mathrm{C}$ ) using a probe-type ultrasonicator (model UIP1000hdT; Hielscher Ultrasonics, Teltow, Germany).

\subsection{In Vitro Tests of Mycelial Growth Inhibition}

The fungicidal potential of the different compounds was determined employing an agar dilution method [39]; briefly, aliquots of stock solutions were incorporated onto the PDA medium to obtain the usual concentrations defined in the EUCAST standard antifungal susceptibility testing procedures [40]. Then, mycelial plugs $(\varnothing=5 \mathrm{~mm})$ of each pathogen coming from the margin of 7-day-old PDA cultures were transferred to plates incorporating the above mentioned concentrations for each compound ( 3 plates per treatment/concentration, with 2 replicates) and incubated 7 days at $25^{\circ} \mathrm{C}$ in the dark. Control plates consisted of PDA medium without any amendment. 
Mycelial growth rates were determined by calculating the average diameter of 2 perpendicular colony axes for each replicate. Growth inhibition of each treatment and concentration was calculated at the end of the incubating period according to the formula:

$$
\left(\left(d_{c}-d_{t}\right) / d_{c}\right) \times 100,
$$

where $d_{c}$ represents the average diameter of the fungal colony of the control and $d_{t}$ is the average diameter of the treated fungal colony.

Results were also expressed as both $\mathrm{EC}_{50}$ and $90 \%$ effective concentrations, estimated by means of PROBIT analysis in IBM SPSS Statistics v.25 (IBM; Armonk, NY, USA) software.

Synergy factors were determined according to Wadley's method to quantify the level of interaction [41].

\subsection{Greenhouse Bioassays in Grafted Plants}

Together with the experiments of fungal pathogens growth inhibition in vitro, bioassays with the mentioned natural products and formulations were performed in grapevine plants in order to scale the protective capabilities of these compounds against three Botryosphaeriaceae species responsible of GTDs on young grapevine plants. Thus, plant material consisted of 48 plants each of varieties "Tempranillo" (CL. 32 clone) (2-years old) and "Garnacha" (VCR3 clone) (one year old) grafted on 775P and 110R rootstocks, respectively. Plants were planted on $3.5 \mathrm{~L}$ plastic pots with a mixed substrate of peat and autoclaved natural soil (75:25), incorporating slow release fertilizer when needed. Plants were maintained in the greenhouse with drip irrigation and anti-weed ground cover for six months (June-December) (Figure 1a). One week after placing them in the greenhouse, grafted plants were inoculated with three pathogens and either COS or COS-Tyr treatments. Five repetitions were arranged for each pathogen/control product and grapevine plant combination (cultivar/rootstock), together with 4 repetitions per pathogen and variety as positive control plus 3 repetitions of negative controls (inoculating only the bioactive product) for each treatment (Table S1).
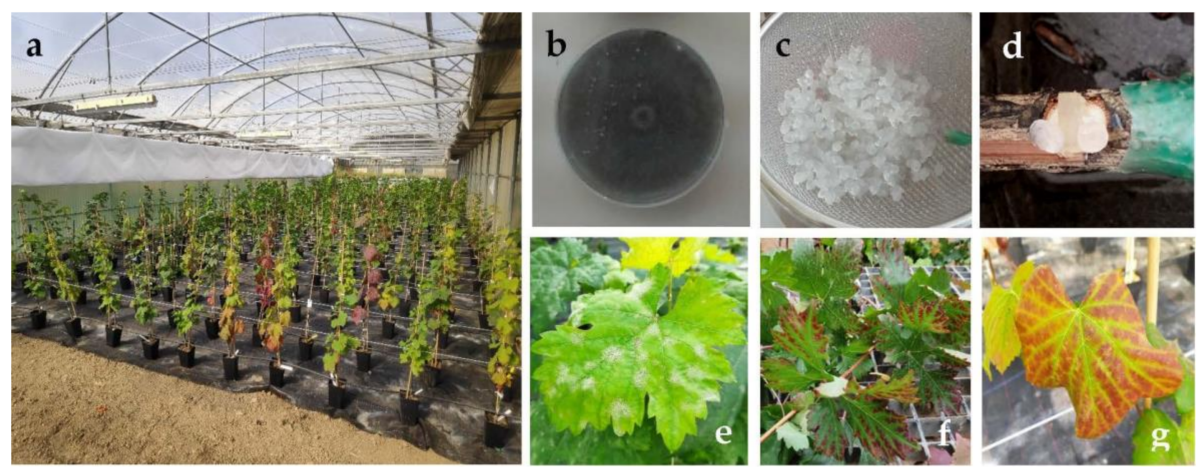

Figure 1. Bioassays in the greenhouse with grafted grapevine plants. (a): Bioassay overview; (b): fresh culture of Neofussicoccum parvum on PDA plate; (c): calcium alginate beads including control product; (d): inoculation method; (e): leaves infected with powdery mildew; $(\mathbf{f}, \mathbf{g})$ : presence of foliar symptoms in grapevine plants.

For the fungal inocula, pure cultures of N. paroum, D. seriata and B. dothidea were maintained as fresh colonies in $9 \mathrm{~cm} \varnothing$ Petri dishes with PDA medium at $25^{\circ} \mathrm{C}$ in the dark (Figure 1b). When necessary, the strains were subcultured in the aforementioned medium to keep them fresh and viable before use. Inoculations of both pathogens and control products were carried out on the trunk of the living plants at two sites per individual (separated at least $5 \mathrm{~cm}$ among them) below the grafting point and not reaching the root crown. In the case of fungal strains, agar plugs from fresh PDA cultures of each fungus in question were used as fungal inoculum. In the defined points of each grapevine plant, slits (with a scalpel) of approx. $3 \mathrm{~mm}$ in diameter and $0.5 \mathrm{~cm}$ deep were done. After this, 
$0.5 \mathrm{~cm}$ diameter agar plugs were inoculated and placed in such a way that the mycelium was in contact with the incision of the stem. Two calcium alginate beads (Figure 1c) including the different control products assayed were placed at both sides of the agar plug (Figure 1d). For this, beads were prepared as follows; each biological compound was added to a $3 \%$ sodium alginate solution in a $2: 8$ ratio $(20 \mathrm{~mL}$ treatment $/ 80 \mathrm{~mL}$ sodium alginate). Then, the solution incorporating each treatment was dispensed drop by drop onto a $3 \%$ calcium carbonate solution to spherify (polymerize) the beads containing the mentioned treatments. Finally, both discs and beads were covered with cotton soaked in sterile double distilled water and sealed with Parafilm ${ }^{\mathrm{TM}}$ tape. During the culturing period, application of copper to control powdery mildew (Figure 1e) was performed in mid-July, together with a first sprouting (followed by periodic sprouting). In addition, releasing of Amblyseius (Typhlodromips) swirskii Athias-Henriot for biological control of whitefly, thrips and spider mite, Encarsia formosa Gahan/Eretmocerus eremicus Rose \& Zolnerowich for whitefly and Aphelinus abdominalis Dalman for aphids at the end of July (Biobest Group NV, Almería, Spain) were also performed.

Potted grapevine plants were examined weekly during the whole assay period by taking photographs (Figure 1f,g) in cases where different foliar symptoms including internervial necroses) were observed. Six months after inoculation, plants were removed and two sections of the inoculated stems between the grafting point and the root crown were prepared, opened longitudinally and the length of the vascular necroses (tracheomycosis) caused by the different pathogens was evaluated. For this, the length of the vascular necroses was measured longitudinally on upper and lower directions from the inoculation point for both halves of the longitudinal cut, and the measures of these were statistically analyzed and compared depending on the type of pathogen and product formulation employed. All the data were compared with controls.

At the beginning of the assay, some of the grapevine plants did not sprout or died in the first month after transplantation. These were removed and examined to verify the presence of pre-existing root rot in the plant material related to this circumstance, and analyzed in the laboratory to isolate the possible responsible fungal species. The rest of the plants removed and measured at the end of the assay were finally processed to re-isolate the different pathogenic taxa previously inoculated. Thus, in order to fulfill Koch's postulates, wood fragments approximately $0.5 \mathrm{~cm}$ long surrounding the different vascular necroses (1-2 cm around the wounds) were washed, surface sterilized, placed in PDA plates amended with streptomycin sulphate (to avoid bacterial contamination) and incubated at $26^{\circ} \mathrm{C}$ in the dark in a culture chamber for 2-3 days.

\subsection{Statistical Analyses}

Differences in the in vitro mycelial growth inhibition results were assessed by analysis of variance (ANOVA) followed by post hoc comparison of means through Tukey's test at $p<0.05$ (provided that the homogeneity and homoscedasticity requirements were satisfied, according to the Shapiro-Wilk and Levene tests [42]). In the case of in planta results, the Johnson transformation $[43,44]$ was first used to transform the data to follow a normal distribution, and then descriptive statistics, ANOVA and Tukey's tests of the necrosis lengths were performed. The SPSS Statistics v.25 software was used (IBM; Armonk, NY, USA).

\section{Results}

Below are shown the results of the assays carried out to test the antifungal capacity of a series of conjugates based on chitosan polymers and certain amino acids, for the control, both in vitro and in plant, of some taxa of the Botrysphaeriaceae family involved in the so-called wood diseases in young grapevine plants.

\subsection{Mycelial Growth Inhibition Tests}

The results of the growth inhibition tests are presented in Figure 2. The performances of the amino acid-only treatments were much lower than those of the treatments based on 
COS, either alone or in combination with them (Figures S1-S3). Concerning the dosage of the compounds assayed, higher inhibition was obtained upon increase of the concentration for all treatments.
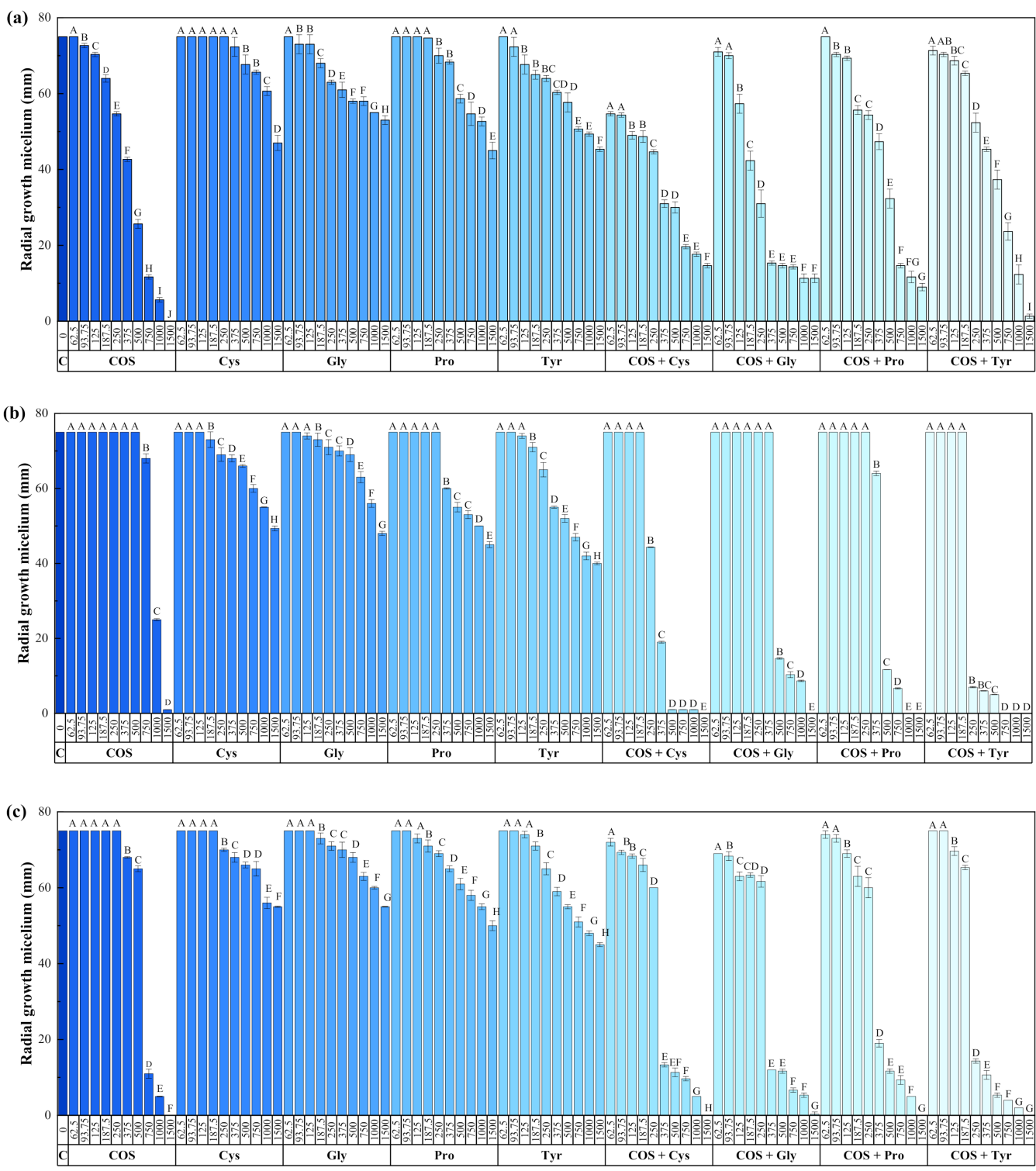

Figure 2. Colony growth values of (a) N. parvum, (b) D. seriata and (c) B. dothidea strains when cultured in PDA plates containing several control products, i.e., chitosan oligomers (COS), cysteine (Cys), glycine (Gly), proline (Pro), tyrosine (Tyr), and the respective COS-amino acid (1:1 v/v) conjugate compounds. The same letters above concentrations mean that they are not significantly different at $p<0.05$. Error bars represent standard deviations.

The effective in vitro concentrations are summarized in Table 1 for comparison purposes (effective concentrations for amino acids alone are not presented, provided that full inhibition was not attained even at the highest assayed concentration, so a reliable fitting could not be obtained). In the case of N. parvum, a synergistic effect was only observed for COS-Cys and COS-Tyr in the $\mathrm{EC}_{50}$ values. Conversely, for D. seriata and B. dothidea, a synergistic effect was observed for all the COS-amino acid conjugate complexes, particularly evident for COS-Tyr, with estimated synergy factors (SF) of 2.03 and 2.29 in the $\mathrm{EC}_{50}$ values and $\mathrm{SF}$ of 2.48 and 2.84 in the $\mathrm{EC}_{90}$ values, respectively. 
Table 1. $\mathrm{EC}_{50}$ and $\mathrm{EC}_{90}$ effective concentrations, expressed in $\mu \mathrm{g} \cdot \mathrm{mL}^{-1}$.

\begin{tabular}{ccccccc}
\hline Pathogen & $\begin{array}{c}\text { Effective } \\
\text { Concentration }\end{array}$ & COS & COS-Cys & COS-Gly & COS-Pro & COS-Tyr \\
\hline \multirow{2}{*}{ N. parvum } & $\mathrm{EC}_{50}$ & 320.9 & 208.8 & 417.8 & 402.9 & 258.9 \\
& $\mathrm{EC}_{90}$ & 967.4 & 1347.0 & 1498.5 & 1439.0 & 1021.4 \\
\hline \multirow{2}{*}{ D. seriata } & $\mathrm{EC}_{50}$ & 448.1 & 297.8 & 448.5 & 398.7 & 254.6 \\
& $\mathrm{EC}_{90}$ & 1360.6 & 774.6 & 1286.7 & 1086.5 & 672.1 \\
\hline \multirow{2}{*}{ B. dothidea } & $\mathrm{EC}_{50}$ & 425.8 & 306.2 & 291.1 & 316.0 & 255.1 \\
& $\mathrm{EC}_{90}$ & 1339.2 & 897.9 & 887.9 & 907.4 & 707.7 \\
\hline
\end{tabular}

$\overline{\mathrm{COS}}=$ chitosan oligomers; Cys = cysteine; Gly = glycine; Pro = proline; Tyr = tyrosine.

\subsection{In Vivo Tests}

After removing, cutting and measuring vascular necroses present in the different treated grafted plants, it was primarily observed that no statistically significant differences were obtained among neither between plant combination (cultivar/rootstock) nor between upper and lower wounds (Figure S4). In fact, in this latter case, the Pearson correlation coefficient was 0.738 .

Upon comparison of necrosis lengths in the negative controls (i.e., plants whose wounds were only treated with the bioactive product, with no pathogen inoculation) and positive controls (i.e., plants inoculated only with pathogens), significant differences between pathogens in terms of their aggressiveness were only observed for the lower wound (Table S2). The most aggressive fungus was N. parvum, while D. seriata showed an intermediate virulence, and B. dothidea induced the least necrosis. This can be ascribed to both differences in the wood decay enzymatic activities and in the ability of these fungi to metabolize major grapevine phytoalexins $[45,46]$.

When the effect of the treatments on the infection rates of the three pathogens was studied, significant differences were found between the treated plants and the positive control in the case of N. parvum and B. dothidea (Table 2). On the other hand, the synergistic behavior between COS and tyrosine observed in vitro (particularly evident for $B$. dothidea) was not reflected in statistically significant differences (compared with single COS treatment) in the plant bioassay at the greenhouse scale.

Table 2. Analysis of variance (ANOVA) of the lengths of vascular necroses for N. parvum (left), B. dothidea (center) and D. seriata (right).

\begin{tabular}{|c|c|c|c|c|c|c|c|c|}
\hline N. paroum & $\begin{array}{l}\text { Upper } \\
\text { Wound }\end{array}$ & $\begin{array}{l}\text { Lower } \\
\text { Wound }\end{array}$ & B. dothidea & $\begin{array}{l}\text { Upper } \\
\text { Wound }\end{array}$ & $\begin{array}{l}\text { Lower } \\
\text { Wound }\end{array}$ & D. seriata & $\begin{array}{l}\text { Upper } \\
\text { Wound }\end{array}$ & $\begin{array}{l}\text { Lower } \\
\text { Wound }\end{array}$ \\
\hline $\begin{array}{c}\text { Positive } \\
\text { control }\end{array}$ & $0.848 \mathrm{a}$ & $0.895 \mathrm{a}$ & $\begin{array}{c}\text { Positive } \\
\text { control }\end{array}$ & $0.529 \mathrm{a}$ & $0.397 \mathrm{a}$ & $\begin{array}{c}\text { Positive } \\
\text { control }\end{array}$ & $0.609 a$ & $0.486 \mathrm{a}$ \\
\hline COS & $0.258 \mathrm{~b}$ & $0.351 \mathrm{~b}$ & COS-Tyr & $-0.121 b$ & $-0.196 b$ & COS & $0.145 \mathrm{~b}$ & $0.412 \mathrm{a}$ \\
\hline COS-Tyr & $0.257 \mathrm{~b}$ & $0.217 \mathrm{~b}$ & $\cos$ & $-0.136 b$ & $-0.236 \mathrm{~b}$ & $\cos +$ tyr & $0.332 \mathrm{ab}$ & $0.279 \mathrm{a}$ \\
\hline $\begin{array}{c}\text { Negative } \\
\text { control }\end{array}$ & $-1.444 \mathrm{c}$ & $-1.210 \mathrm{c}$ & $\begin{array}{c}\text { Negative } \\
\text { control }\end{array}$ & $-1.444 \mathrm{c}$ & $-1.210 \mathrm{c}$ & $\begin{array}{c}\text { Negative } \\
\text { control }\end{array}$ & $-1.444 \mathrm{c}$ & $-1.210 b$ \\
\hline $\operatorname{Pr}>F$ & $<0.0001$ & $<0.0001$ & $\operatorname{Pr}>F$ & $<0.0001$ & $<0.0001$ & $\operatorname{Pr}>F$ & $<0.0001$ & $<0.0001$ \\
\hline Significant & Yes & Yes & Significant & Yes & Yes & Significant & Yes & Yes \\
\hline
\end{tabular}

Treatments/controls labelled with the same letters are not significantly different at $p<0.05$.

Finally, in the case of $D$. seriata, significant differences were only observed in the upper wounds, with a better performance of the treatment based solely on COS, an unexpected result on the basis of the effective concentration values reported in Table 1. In the lower wounds, no significant differences were seen, but the COS-Tyr treatment seemed to show a better performance than that based solely on COS, in line with the results of the in vitro tests. 
Plants prematurely removed from the bioassay displayed basal rots (due to Rhizoctonia solani J.G. Kühn and Neonectria spp.) already present in the starting material. Moreover, the rest of the plants of the assay were submitted to Koch' postulates, isolating the previously inoculated pathogens in most $(80 \%)$ of them.

As previously mentioned, together with the vascular necrosis, during the whole assay period it was observed that many of the grapevine plants exhibited certain foliar symptoms (Figure 1f,g), probably due to a long-dispersal action of phytotoxins produced by the inoculated pathogens. The production of such type of secondary metabolites by these and other GTD-related fungi is well known [7,47-49]. Among these, low molecular weight lipophilic phytotoxins (for example, naphthalenone pentaketides, melleins and polyphenols) produced by the different Bot taxa could be responsible for the observed symptoms (i.e., moderate to severe withering and necrotic spots). When analyzing such symptoms, no correlations were observed among either the plants inoculated exclusively with the pathogens and the controls without any fungus or the treated plants, probably due to the basal phytosanitary status of the propagation material, which could also influence the appearance of these foliar symptoms, regardless the treatment assayed.

\section{Discussion}

\subsection{Comparison of the Efficacy of the Treatments}

Regarding chitosan only-based treatments, chitosan oligosaccharides (molecular weight $<3000 \mathrm{Da}$ ) at a concentration of $1000 \mu \mathrm{g} \cdot \mathrm{mL}^{-1}$ were reported to completely inhibit the mycelial growth of $D$. seriata and B. dothidea when performing in vitro assays [29]. These values are of the same order of magnitude as the $\mathrm{EC}_{90}$ values presented herein, so differences may be attributed to the isolate-dependency of the susceptibility profile.

For the same strains of N. paroum and D. seriata, EC 90 values of 1270 and $1120.7 \mu \mathrm{g} \cdot \mathrm{mL}^{-1}$ were attained for COS with molecular weight < $2000 \mathrm{Da}$ in [33]. In this case, differences may be tentatively ascribed to slight differences in the molecular weight, polymerization degree or deacetylation degree of COS, which are known to influence its efficacy against phytopathogenic fungi $[50,51]$.

In relation to non-in vitro bioassays with chitosan, Cobos, Mateos, Alvarez-Perez, Olego, Sevillano, Gonzalez-Garcia, Garzon-Jimeno and Coque [29] reported that 96.8\% growth inhibition of $D$. seriata was attained in autoclaved vine shoots using chitosan oligosaccharides, although at a much higher concentration $\left(25 \mathrm{mg} \cdot \mathrm{mL}^{-1}\right)$. In artificially inoculated plants, the same authors found a significant reduction in the incidence of $D$. seriata when the pruning wounds were treated with chitosan oligosaccharides and other natural compounds, decreasing lipid peroxidation levels and guaiacol peroxidase (GPX) activity (a recognized stress marker). Albeit for different GTD pathogens, Nascimento, Rego and Oliveira [30] - in greenhouse experiments carried on potted grapevine plants (cultivar "Castelão") growing in a substrate artificially infested with Phaeomoniella chlamydospora or Neonectria liriodendri-observed that foliar sprays of chitosan oligosaccharin $(<3 \mathrm{kDa})$ only reduced the disease incidence of $P$. chlamydospora, but had an effect against $N$. liriodendri similar to that of some selected fungicides (tebuconazole, cyprodinil + fludioxonil and carbendazim + flusilazole).

Concerning aminoacids, cysteine has been reported to have an inhibitory effect on the in vitro mycelial growth of P. chlamydospora and Phaeoacremonium minimum; at a concentration of $10 \mathrm{mM}$ (that is, $1216 \mu \mathrm{g} \cdot \mathrm{mL}^{-1}$ ), an inhibition of $77 \%$ for $P$. chlamydospora and $58 \%$ for $P$. minimum was attained. The respective $\mathrm{EC}_{100}$ values were 15 and $20 \mathrm{mM}$ $\left(1824\right.$ and $\left.2432 \mu \mathrm{g} \cdot \mathrm{mL}^{-1}\right)$ [28]. At a $10 \mathrm{mM}$ concentration, it exhibited a strong inhibition $(79-100 \%)$ against various strains of E. lata, while lower efficacies were observed against other fungal species associated with other grapevine diseases ( $P$. chlamydospora and Phaeoacremonium aleophilum, Botryosphaeria parva and B. obtusa, that were inhibited by 63\%, $40 \%, 54 \%$ and $40 \%$, respectively) [52].

Regarding analogous polysaccharide-peptide based formulations, little information is available in the literature. The $\mathrm{EC}_{90}$ values attained with a COS- - -polylysine conjugate 
(507.5, 580.2 and $497.4 \mu \mathrm{g} \cdot \mathrm{mL}^{-1}$ for N. parvum, D. seriata and B. dothidea, respectively [33]) were better than those attained in this work for the COS-Tyr conjugate $(1021.4,672.1$ and $707.7 \mu \mathrm{g} \cdot \mathrm{mL}^{-1}$, respectively), but-from an economic perspective-the latter formulation would be much more viable (given that the price of $\varepsilon$-polylysine is much higher than that of tyrosine: $245 € / 100 \mathrm{mg}$ vs. $58 € / 100 \mathrm{~g}$ ). An additional advantage of the COS-Tyr formulation could be its versatility as a crop protection product: $\mathrm{EC}_{50}$ and $\mathrm{EC}_{90}$ values against Fusarium culmorum (320 and $1107 \mu \mathrm{g} \cdot \mathrm{mL}^{-1}$, respectively) were of the same order of magnitude as those reported herein [37].

If the $\mathrm{EC}_{50}$ values for COS and the COS-amino acid conjugate complexes are compared with those reported for chemical fungicides used in GTDs control, it may be observed that the efficacies would be comparable: for example, Pitt, et al. [53] found values in the 360$440,530-620$ and $450 \mu \mathrm{g} \cdot \mathrm{mL}^{-1}$ range for $N$. parvum, D. seriata and B. dothidea, respectively, taking data pooled across fungicides (viz. carbendazim, fluazinam, fludioxonil, flusilazole, iprodione, myclobutanil, penconazole, procymidone, pyraclostrobin and tebuconazole) to estimate average $\mathrm{EC}_{50}$ values for isolate sensitivity. Nonetheless, if one considers the excellent $\mathrm{EC}_{50}$ values reported by Olmo, et al. [54] against $N$. parvum and D. seriata for tebuconazole (90 and $150 \mu \mathrm{g} \cdot \mathrm{mL}^{-1}$, respectively) and pyraclostrobin $\left(100\right.$ and $250 \mu \mathrm{g} \cdot \mathrm{mL}^{-1}$, respectively), it becomes apparent that there is still room for improvement in the efficacy of the natural composites.

\subsection{Mechanism of Action}

A panorama of the molecular mechanisms behind chitosan interactions with plants and fungi has been recently presented in the review paper by Lopez-Moya, et al. [55]. With regard to its role as an antimicrobial agent, it is well established that it can permeabilize fungal plasmatic membranes (triggering intracellular production of ROS and cell death), arrest germination and growth by deprivation of nutrients (which leads to cell wall architecture modification), alter gene expression (e.g., affecting oxidoreductase activity, respiration and transport gene ontology functions), etc.

Regarding the precise function of amino acids in the response of plants to pathogens, it is not well established: on one hand, they are required for growth and metabolism in microorganisms, and on the other hand, careful optimization of composition and concentration can produce antimicrobial effects [56]. Besides this, changes in the contents of amino acids appear to be a common characteristic of plant response to GTDs. For instance, in a recent study of the wood metabolomic responses of wild (Vitis vinifera subsp. sylvestris) and cultivated grapevine (V. v. subsp. vinifera) to infection with N. parvum, Labois, et al. [57] found that the metabolic response of the former to the infection featured a faster and more intense alteration in primary metabolites in comparison to the latter, accompanied by a higher induction of various resveratrol oligomer contents. Infection by N. parvum caused an increase in alanine, $\beta$-alanine and glycine, and a decrease in aspartic acid, asparagine and serine.

To the best of the authors' knowledge, no data on the role of tyrosine on GTDs has been published to date. Nonetheless, cysteine has been reported to be involved in signaling, plant resistance and antifungal development [27]. Like other amino acids, cysteine can be transported along the vascular tissues of vines over long distances, and it can induce dramatic alterations in the structural organization of the mycelium (nucleus, mitochondria, vacuoles and cell wall), causing the death of the hyphae [52]. Octave, Amborabé, Luini, Ferreira, Fleurat-Lessard and Roblin [52] hypothesized that the action of cysteine may be based on its ability to interfere with a certain metabolic pathway and also by triggering the secretion of ergosterol, which presents properties of an elicitor.

As regards the mode of action of the conjugate complex, it may be the result of an enhanced additive fungicidal effect per se, and/or via a concurrent action on diverse fungal metabolic sites. In a previous work [37], we also hypothesized that conjugation of COS and Tyr increases the cationic surface charge of COS, enhancing the linkage (through 
electrostatic interactions) to the negatively charged site-specific binding receptors on the fungal membrane.

\subsection{Significance of the Reported Findings}

The three fungal species tested in the present study belong to the Botryosphaeriaceae family, a group of polyphagous ascomycetous taxa associated not only with grapevine diseases, but also pathogenic on a vast range of woody plants, specially forestry species [58], stone and pome fruits (i.e., almond, peach, apple, apricot, etc.) [59], and even on woody crops of recent implantation and extension in Spain such as pistachio [60,61]. Furthermore, $D$. seriata and B. dothidea have been cited as phytopathogens on apple [62], while N. parvum causes avocado dieback [63], B. dothidea causes Botryosphaeria blights and cankers on olive trees [64], and as mentioned, the three of them are commonly related to branch cankers on almond trees [54]. Therefore, the findings obtained in the present study may also be applied and extended to other basic Mediterranean crops that usually share these types of pathogens. In fact, many authors have verified that many of the pathogens of crops such as olive, stone fruit or grapevine, share plant hosts during some phase of their life cycle and are isolated repeatedly from adjacent crops [65], resulting in an even higher ecological and economic impact. Thus, any type of research in the control of global and aggressive pathogens such as B. dothidea [66] or N. paroum [67] is relevant, since the incidence and economic importance of the losses caused by both fungi has been increasing in recent years, especially in grapevine crop due to damage to young plants coming from the nursery. Both taxa tend to have a prolonged latent or endophytic phase [68], which makes their detection very difficult, especially in quarantine inspection surveys, since their symptoms occasionally appear in situations of stress of the plant host. Furthermore, in the nurseries that produce young grafted vine plants in Spain, N. parvum is considered one of the main mycoses associated with propagation material [69], being ultimately responsible for the uprooting of thousands of hectares of grapevine plants in the first years after their plantation.

\subsection{Limitations of the Study and Further Research}

A clear limiting factor in the in planta bioassays was the choice of calcium alginate as a dispersion medium to protect the pruning wounds, given that it limited the amount of the bioactive solution that could be incorporated to the matrix to approximately $20 \%$ (otherwise gelation was not attained). Considering that the initial concentration of the bioactive solutions was $3000 \mu \mathrm{g} \cdot \mathrm{mL}^{-1}$, the formulations were tested at a concentration of $c a .600 \mu \mathrm{g} \cdot \mathrm{mL}^{-1}$, that is, at values closer in many cases to the $\mathrm{EC}_{50}$ value than to the $\mathrm{EC}_{90}$ one. This would explain why, even though significant differences were observed, a higher degree of protection was not attained. The use of other thickener agents (e.g., pectin, vegetable gums, starches, or halloysite, which are cheaper than alginate) should be assayed in future studies. Alternatively, more advanced delivery methods, such as the use of lignin nanocarriers (analogous to those recently reported by Wurm's group [70,71] for azoxystrobin, pyraclostrobin, tebuconazole, and boscalid delivery) could overcome the aforementioned limitation.

Since the results obtained here refer only to the reduction of vascular necrosis in artificially inoculated grapevine plants, complementary tests will be required in future multiyear assays to correlate these levels of protection with the intensity and incidence of foliar symptoms, harvest yield, etc., to have a more complete view of the effect of this type of alternative substances.

Another particularly interesting aspect to be considered in follow-up studies would be the inclusion of synthetic chemicals as additional treatments, provided that this would allow direct comparisons with the natural products both in terms of efficacy and costeffectiveness. 


\section{Conclusions}

Conjugate complexes of chitosan oligomers (with $\mathrm{MW}<2 \mathrm{kDa}$ ) and amino acids, inspired in plant HDPs, were assayed for their control effects against three Botryosphaeriaceae fungi responsible for some of the GTDs. In vitro growth inhibition tests revealed a synergistic effect between COS and the amino acids against two of the pathogens, viz. D. seriata and B. dothidea, which was not present (or was very weak) in the case of N. parvum. The lowest $\mathrm{EC}_{50}$ and $\mathrm{EC}_{90}$ effective concentrations, comparable to those reported for conventional synthetic fungicides used in the control of these mycoses, were obtained for the COS-tyrosine conjugate complex. Hence, this formulation and the one based on COS alone were further assayed for wound protection applications in a greenhouse bioassay conducted on potted grapevines of two varieties ("Tempranillo" on 775P and "Garnacha" on 110R rootstock), which were artificially inoculated with the mentioned pathogenic species. A significant decrease in vascular necrosis severity was observed for $N$. parvum and B. dothidea, while the efficacy against $D$. seriata was only statistically significant for the upper wounds. Taking into consideration that the incidence and economic importance of the losses caused by the former two fungi has been increasing in recent years, and that they affect many other woody plants (not only grapevine), the reported formulations may pose a promising alternative to synthetic chemical pesticides for the protection of trunk diseases of woody crops.

\section{Patents}

The work reported in this manuscript is related to Spanish patents P201931118 and P201831106.

Supplementary Materials: The following are available online at https://www.mdpi.com/2073-439 5/11/2/324/s1, Figures S1-S3: Sensitivity tests for N. parvum, D. seriata and B. dothidea; Figure S4: Box-plot of the lengths of the vascular necroses in the upper and lower wounds; Table S1: Repetitions for each of the plant/treatment combinations in the greenhouse bioassay; Table S2: ANOVA of lengths of the vascular necroses in the positive and negative controls for the three fungi under study.

Author Contributions: Conceptualization, E.P.-L., J.M.-G. and V.G.-G.; methodology, J.M.-G., J.C.-G. and V.G.-G.; validation, J.C.-G., V.G.-G. and P.M.-R.; formal analysis, J.C.-G., V.G.-G. and P.M.-R.; investigation, L.B.-D., N.L.-L., V.G.-G., J.C.-G., J.M.-G. and P.M.-R.; resources, J.M.-G. and P.M.-R.; data curation, J.C.-G.; writing—original draft preparation, L.B.-D., N.L.-L., V.G.-G., J.C.-G., J.M.-G. and P.M.-R.; writing—review and editing, V.G.-G. and P.M.-R.; visualization, L.B.-D. and N.L.-L.; supervision, V.G.-G. and P.M.-R.; project administration, V.G.-G., J.M.-G. and P.M.-R.; funding acquisition, J.M.-G. and P.M.-R. All authors have read and agreed to the published version of the manuscript.

Funding: This research was funded by Junta de Castilla y León under project VA258P18, with FEDER co-funding, and by Universidad de Zaragoza under project UZ2019-TEC-07.

Informed Consent Statement: Not applicable.

Data Availability Statement: The data presented in this study are available on request from the corresponding author. The data are not publicly available due to their relevance as part of an ongoing PhD Thesis.

Acknowledgments: V.G.-G thanks C. Julián (Plant Protection Unit, CITA) for her technical assistance. L.B.-D. gratefully acknowledges the support of Gregorio Michu in the in vitro tests.

Conflicts of Interest: The authors declare no conflict of interest. The funders had no role in the design of the study; in the collection, analyses, or interpretation of data; in the writing of the manuscript, or in the decision to publish the results.

\section{References}

1. Mondello, V.; Songy, A.; Battiston, E.; Pinto, C.; Coppin, C.; Trotel-Aziz, P.; Clement, C.; Mugnai, L.; Fontaine, F. Grapevine Trunk Diseases: A Review of Fifteen Years of Trials for Their Control with Chemicals and Biocontrol Agents. Plant Dis. 2018, 102, 1189-1217. [CrossRef]

2. Peil, S.; Beckers, S.J.; Fischer, J.; Wurm, F.R. Biodegradable, lignin-based encapsulation enables delivery of Trichoderma reesei with programmed enzymatic release against grapevine trunk diseases. Mater Today Bio 2020, 7, 100061. [CrossRef] 
3. Gramaje, D.; Urbez-Torres, J.R.; Sosnowski, M.R. Managing Grapevine Trunk Diseases With Respect to Etiology and Epidemiology: Current Strategies and Future Prospects. Plant Dis. 2018, 102, 12-39. [CrossRef]

4. Phillips, A.J.L. Botryosphaeria species associated with diseases of grapevines in Portugal. Phytopathol. Mediterr. 2002, 41, 3-18. [CrossRef]

5. Taylor, A.; St, J.; Hardy, G.E.; Wood, P.; Burgess, T. Identification and pathogenicity ofBotryosphaeriaspecies associated with grapevine decline in Western Australia. Australas. Plant. Pathology 2005, 34, 34. [CrossRef]

6. Martos, S.; Andolfi, A.; Luque, J.; Mugnai, L.; Surico, G.; Evidente, A. Production of phytotoxic metabolites by five species of Botryosphaeriaceae causing decline on grapevines, with special interest in the species Neofusicoccum luteum and N. parvum. Eur. J. Plant Pathol. 2008, 121, 451-461. [CrossRef]

7. Andolfi, A.; Mugnai, L.; Luque, J.; Surico, G.; Cimmino, A.; Evidente, A. Phytotoxins Produced by Fungi Associated with Grapevine Trunk Diseases. Toxins 2011, 3, 1569-1605. [CrossRef] [PubMed]

8. Vincenzo, M.; Philippe, L.; Josep, A.; Andreas, K.; Kalman, V.; Fanny, P.; Eric, S.; Cecilia, R.; Laura, M.; Florence, F. Management of grapevine trunk diseases: Kowledge transfer, current strategies and innovative strategies adopted in Europe. Phytopathol. Mediterr. 2018, 57. [CrossRef]

9. Del Frari, G.; Gobbi, A.; Aggerbeck, M.R.; Oliveira, H.; Hansen, L.H.; Ferreira, R.B. Fungicides and the Grapevine Wood Mycobiome: A Case Study on Tracheomycotic Ascomycete Phaeomoniella chlamydospora Reveals Potential for Two Novel Control Strategies. Front. Plant. Science 2019, 10. [CrossRef] [PubMed]

10. Grozić, K.; Bubola, M.; Poljuha, D. Symptoms and management of grapevine trunk diseases. J. Cent. Eur. Agric. 2019, 20, 876-890. [CrossRef]

11. Chacón, J.L.; Gramaje, D.; Izquierdo, P.M.; Martínez, J.; Mena, A. Evaluation of six red grapevine cultivars inoculated with Neofusicoccum paroum. Eur. J. Plant Pathol. 2020, 158, 811-815. [CrossRef]

12. Martinez-Diz, M.d.P.; Diaz-Losada, E.; Barajas, E.; Ruano-Rosa, D.; Andres-Sodupe, M.; Gramaje, D. Screening of Spanish Vitis vinifera germplasm for resistance to Phaeomoniella chlamydospora. Sci. Hortic. 2019, 246, 104-109. [CrossRef]

13. Gramaje, D.; Alaniz, S.; Abad-Campos, P.; Garcia-Jimenez, J.; Armengol, J. Evaluation of grapevine rootstocks against soilborne pathogens associated with trunk diseases. Acta Hortic. 2016, 1136, 245-249. [CrossRef]

14. Guan, X.; Essakhi, S.; Laloue, H.; Nick, P.; Bertsch, C.; Chong, J. Mining new resources for grape resistance against Botryosphaeriaceae: A focus on Vitis vinifera subsp sylvestris. Plant Pathol. 2016, 65, 273-284. [CrossRef]

15. Murolo, S.; Romanazzi, G. Effects of grapevine cultivar, rootstock and clone on esca disease. Australas. Plant. Pathology 2014, 43, 215-221. [CrossRef]

16. Travadon, R.; Rolshausen, P.E.; Gubler, W.D.; Cadle-Davidson, L.; Baumgartner, K. Susceptibility of Cultivated and Wild Vitis spp. to Wood Infection by Fungal Trunk Pathogens. Plant Dis. 2013, 97, 1529-1536. [CrossRef]

17. Martinez-Diz, M.d.P.; Diaz-Losada, E.; Andres-Sodupe, M.; Bujanda, R.; Maldonado-Gonzalez, M.M.; Ojeda, S.; Yacoub, A.; Rey, P.; Gramaje, D. Field evaluation of biocontrol agents against black-foot and Petri diseases of grapevine. Pest. Manag. Sci. 2020 [CrossRef]

18. Pertot, I.; Caffi, T.; Rossi, V.; Mugnai, L.; Hoffmann, C.; Grando, M.S.; Gary, C.; Lafond, D.; Duso, C.; Thiery, D.; et al. A critical review of plant protection tools for reducing pesticide use on grapevine and new perspectives for the implementation of IPM in viticulture. Crop. Protect. 2017, 97, 70-84. [CrossRef]

19. Song, H.-Q.; Fan, Y.; Hu, Y.; Cheng, G.; Xu, F.-J. Polysaccharide-Peptide Conjugates: A Versatile Material Platform for Biomedical Applications. Adv. Funct. Mater. 2020. [CrossRef]

20. Dos Santos-Silva, C.A.; Zupin, L.; Oliveira-Lima, M.; Vilela, L.M.B.; Bezerra-Neto, J.P.; Ferreira-Neto, J.R.; Ferreira, J.D.C.; de Oliveira-Silva, R.L.; Pires, C.d.J.; Aburjaile, F.F.; et al. Plant Antimicrobial Peptides: State of the Art, In Silico Prediction and Perspectives in the Omics Era. Bioinf. Biol. Insights 2020, 14. [CrossRef]

21. Sathoff, A.E.; Samac, D.A. Antibacterial Activity of Plant Defensins. Mol. Plant-Microbe Interact. 2019, 32, 507-514. [CrossRef]

22. Su, T.; Han, M.; Cao, D.; Xu, M. Molecular and Biological Properties of Snakins: The Foremost Cysteine-Rich Plant Host Defense Peptides. J. Fungi 2020, 6, 220. [CrossRef]

23. Kundu, R. Cationic Amphiphilic Peptides: Synthetic Antimicrobial Agents Inspired by Nature. Chemmedchem 2020, 15, 1887-1896. [CrossRef]

24. Srivastava, S.; Dashora, K.; Ameta, K.L.; Singh, N.P.; El-Enshasy, H.A.; Pagano, M.C.; Hesham, A.E.-L.; Sharma, G.D.; Sharma, M.; Bhargava, A. Cysteine-rich antimicrobial peptides from plants: The future of antimicrobial therapy. Phytother. Res. 2020. [CrossRef] [PubMed]

25. Ahmad, B.; Yao, J.; Zhang, S.; Li, X.; Zhang, X.; Yadav, V.; Wang, X. Genome-Wide Characterization and Expression Profiling of GASA Genes during Different Stages of Seed Development in Grapevine (Vitis vinifera L.) Predict Their Involvement in Seed Development. Int. J. Mol. Sci. 2020, 21, 1088. [CrossRef] [PubMed]

26. Álvarez, C.; Ángeles Bermúdez, M.; Romero, L.C.; Gotor, C.; García, I. Cysteine homeostasis plays an essential role in plant immunity. New Phytol. 2012, 193, 165-177. [CrossRef] [PubMed]

27. Roblin, G.; Octave, S.; Faucher, M.; Fleurat-Lessard, P.; Berjeaud, J.-M. Cysteine: A multifaceted amino acid involved in signaling, plant resistance and antifungal development. Plant Physiol. Biochem. 2018, 129, 77-89. [CrossRef] [PubMed] 
28. Roblin, G.; Luini, E.; Fleurat-Lessard, P.; Larignon, P.; Berjeaud, J.-M. Towards a preventive and/or curative treatment of esca in grapevine trunk disease: General basis in the elaboration of treatments to control plant pathogen attacks. Crop Protect. 2019, 116, 156-169. [CrossRef]

29. Cobos, R.; Mateos, R.M.; Alvarez-Perez, J.M.; Olego, M.A.; Sevillano, S.; Gonzalez-Garcia, S.; Garzon-Jimeno, E.; Coque, J.J. Effectiveness of Natural Antifungal Compounds in Controlling Infection by Grapevine Trunk Disease Pathogens through Pruning Wounds. Appl. Environ. Microbiol. 2015, 81, 6474-6483. [CrossRef]

30. Nascimento, T.; Rego, C.; Oliveira, H. Potential use of chitosan in the control of grapevine trunk diseases. Phytopathol. Mediterr. 2007, 46, 218-224.

31. Xing, K.; Shen, X.; Zhu, X.; Ju, X.; Miao, X.; Tian, J.; Feng, Z.; Peng, X.; Jiang, J.; Qin, S. Synthesis and in vitro antifungal efficacy of oleoyl-chitosan nanoparticles against plant pathogenic fungi. Int. J. Biol. Macromol. 2016, 82, 830-836. [CrossRef] [PubMed]

32. Matei, P.M.; Martín-Ramos, P.; Sánchez-Báscones, M.; Hernández-Navarro, S.; Correa-Guimaraes, A.; Navas-Gracia, L.M.; Rufino, C.A.; Ramos-Sánchez, M.C.; Martín-Gil, J. Synthesis of chitosan oligomers/propolis/silver nanoparticles composite systems and study of their activity against Diplodia seriata. Int. J. Polym. Sci. 2015, 2015, 1-11. [CrossRef]

33. Buzón-Durán, L.; Martín-Gil, J.; Pérez-Lebeña, E.; Ruano-Rosa, D.; Revuelta, J.L.; Casanova-Gascón, J.; Ramos-Sánchez, M.C.; Martín-Ramos, P. Antifungal agents based on chitosan oligomers, $\varepsilon$-polylysine and Streptomyces spp. secondary metabolites against three Botryosphaeriaceae species. Antibiotics 2019, 8, 99. [CrossRef] [PubMed]

34. Monteiro, C.; Fernandes, H.; Oliveira, D.; Vale, N.; Barbosa, M.; Gomes, P.; Martins, M.C.L. AMP-Chitosan Coating with Bactericidal Activity in the Presence of Human Plasma Proteins. Molecules 2020, 25, 3046. [CrossRef]

35. Song, J.; Feng, H.; Wu, M.; Chen, L.; Xia, W.; Zhang, W. Preparation and characterization of arginine-modified chitosan/hydroxypropyl methylcellose antibacterial film. Int. J. Biol. Macromol. 2020, 145, 750-758. [CrossRef]

36. Thappeta, K.R.V.; Vikhe, Y.S.; Yong, A.M.H.; Chan-Park, M.B.; Kline, K.A. Combined Efficacy of an Antimicrobial Cationic Peptide Polymer with Conventional Antibiotics to Combat Multidrug-Resistant Pathogens. Acs Infectious Diseases 2020, 6, $1228-1237$. [CrossRef]

37. Buzón-Durán, L.; Martín-Gil, J.; Marcos-Robles, J.L.; Fombellida-Villafruela, Á.; Pérez-Lebeña, E.; Martín-Ramos, P. Antifungal Activity of Chitosan Oligomers-Amino Acid Conjugate Complexes against Fusarium culmorum in Spelt (Triticum spelta L.). Agronomy 2020, 10, 1427. [CrossRef]

38. Martin, M.T.; Cobos, R. Identification of Fungi Associated with Grapevine Decline in Castilla y León (Spain). Phytopathol. Mediterr. 2007, 46, 18-25.

39. Balouiri, M.; Sadiki, M.; Ibnsouda, S.K. Methods for in vitro evaluating antimicrobial activity: A review. J. Pharm. Anal. 2016, 6 , 71-79. [CrossRef]

40. Arendrup, M.C.; Cuenca-Estrella, M.; Lass-Flörl, C.; Hope, W. EUCAST technical note on the EUCAST definitive document EDef 7.2: Method for the determination of broth dilution minimum inhibitory concentrations of antifungal agents for yeasts EDef 7.2 (EUCAST-AFST)* Clin. Microbiol. Infect. 2012, 18, E246-E247. [CrossRef]

41. Wadley, F.M. The evidence required to show synergistic action of insecticides and a short cut in analysis; U.S. Government Printing Office: Washington, DC, USA, 1945.

42. Glaz, B.; Yeater, K.M. Applied statistics in agricultural, biological, and environmental sciences; American Society of Agronomy, Soil Science Society of America, Crop Science Society of America: Madison, WI, USA, 2018. [CrossRef]

43. Yeo, I.K.; Johnson, R.A. A new family of power transformations to improve normality or symmetry. Biometrika 2000, 87, 954-959. [CrossRef]

44. Piepho, H.-P. Data Transformation in Statistical Analysis of Field Trials with Changing Treatment Variance. Agron. J. 2009, 101, 865-869. [CrossRef]

45. Sarrocco, S.; Stempien, E.; Goddard, M.-L.; Wilhelm, K.; Tarnus, C.; Bertsch, C.; Chong, J. Grapevine Botryosphaeria dieback fungi have specific aggressiveness factor repertory involved in wood decay and stilbene metabolization. PLoS ONE 2017, 12. [CrossRef]

46. Bénard-Gellon, M.; Farine, S.; Goddard, M.L.; Schmitt, M.; Stempien, E.; Pensec, F.; Laloue, H.; Mazet-Kieffer, F.; Fontaine, F.; Larignon, P.; et al. Toxicity of extracellular proteins from Diplodia seriata and Neofusicoccum paroum involved in grapevine Botryosphaeria dieback. Protoplasma 2014, 252, 679-687. [CrossRef]

47. Reveglia, P.; Savocchia, S.; Billones-Baaijens, R.; Masi, M.; Cimmino, A.; Evidente, A. Phytotoxic metabolites by nine species of Botryosphaeriaceae involved in grapevine dieback in Australia and identification of those produced by Diplodia mutila, Diplodia seriata, Neofusicoccum australe and Neofusicoccum luteum. Nat. Prod. Res. 2018, 33, 2223-2229. [CrossRef]

48. Reveglia, P.; Savocchia, S.; Billones-Baaijens, R.; Masi, M.; Evidente, A. Spencertoxin and spencer acid, new phytotoxic derivatives of diacrylic acid and dipyridinbutan-1,4-diol produced by Spencermartinsia viticola, a causal agent of grapevine Botryosphaeria dieback in Australia. Arabian J. Chem. 2020, 13, 1803-1808. [CrossRef]

49. Abou-Mansour, E.; Débieux, J.-L.; Ramírez-Suero, M.; Bénard-Gellon, M.; Magnin-Robert, M.; Spagnolo, A.; Chong, J.; Farine, S.; Bertsch, C.; L'Haridon, F.; et al. Phytotoxic metabolites from Neofusicoccum parvum, a pathogen of Botryosphaeria dieback of grapevine. Phytochemistry 2015, 115, 207-215. [CrossRef] [PubMed]

50. Rahman, M.H.; Hjeljord, L.G.; Aam, B.B.; Sørlie, M.; Tronsmo, A. Antifungal effect of chito-oligosaccharides with different degrees of polymerization. Eur. J. Plant Pathol. 2014, 141, 147-158. [CrossRef]

51. Younes, I.; Sellimi, S.; Rinaudo, M.; Jellouli, K.; Nasri, M. Influence of acetylation degree and molecular weight of homogeneous chitosans on antibacterial and antifungal activities. Int. J. Food Microbiol. 2014, 185, 57-63. [CrossRef] [PubMed] 
52. Octave, S.; Amborabé, B.-E.; Luini, E.; Ferreira, T.; Fleurat-Lessard, P.; Roblin, G. Antifungal effects of cysteine towards Eutypa lata, a pathogen of vineyards. Plant Physiol. Biochem. 2005, 43, 1006-1013. [CrossRef] [PubMed]

53. Pitt, W.M.; Sosnowski, M.R.; Huang, R.; Qiu, Y.; Steel, C.C.; Savocchia, S. Evaluation of fungicides for the management of Botryosphaeria canker of grapevines. Plant Dis. 2012, 96, 1303-1308. [CrossRef]

54. Olmo, D.; Gramaje, D.; Armengol, J. Evaluation of fungicides to protect pruning wounds from Botryosphaeriaceae species infections on almond trees. Phytopathol. Mediterr. 2017, 56, 77-86.

55. Lopez-Moya, F.; Suarez-Fernandez, M.; Vicente Lopez-Llorca, L. Molecular Mechanisms of Chitosan Interactions with Fungi and Plants. Int. J. Mol. Sci. 2019, 20, 332. [CrossRef]

56. Idrees, M.; Mohammad, A.R.; Karodia, N.; Rahman, A. Multimodal Role of Amino Acids in Microbial Control and Drug Development. Antibiotics 2020, 9, 330. [CrossRef] [PubMed]

57. Labois, C.; Wilhelm, K.; Laloue, H.; Tarnus, C.; Bertsch, C.; Goddard, M.-L.; Chong, J. Wood Metabolomic Responses of Wild and Cultivated Grapevine to Infection with Neofusicoccum parvum, a Trunk Disease Pathogen. Metabolites 2020, 10, 232. [CrossRef] [PubMed]

58. Batista, E.; Lopes, A.; Alves, A. Botryosphaeriaceae species on forest trees in Portugal: Diversity, distribution and pathogenicity. Eur. J. Plant Pathol. 2020, 158, 693-720. [CrossRef]

59. Damm, U.; Crous, P.W.; Fourie, P.H. Botryosphaeriaceae as potential pathogens of Prunus species in South Africa, with descriptions of Diplodia africana and Lasiodiplodia plurivora sp. nov. Mycologia 2007, 99, 664-680. [CrossRef]

60. Sohrabi, M.; Mohammadi, H.; León, M.; Armengol, J.; Banihashemi, Z. Fungal pathogens associated with branch and trunk cankers of nut crops in Iran. Eur. J. Plant Pathol. 2020, 157, 327-351. [CrossRef]

61. Moral, J.; Morgan, D.; Trapero, A.; Michailides, T.J. Ecology and Epidemiology of Diseases of Nut Crops and Olives Caused by Botryosphaeriaceae Fungi in California and Spain. Plant Dis. 2019, 103, 1809-1827. [CrossRef]

62. Ahmad, H.; K, V.; K, R.; Bhat, A.; Shah, A. Study of bio-fabrication of iron nanoparticles and their fungicidal property against phytopathogens of apple orchards. IET Nanobiotechnol. 2016, 11, 230-235. [CrossRef]

63. Arjona-Girona, I.; Ruano-Rosa, D.; López-Herrera, C.J. Identification, pathogenicity and distribution of the causal agents of dieback in avocado orchards in Spain. Span. J. Agric. Res. 2019, 17, e1003. [CrossRef]

64. Moral, J.; Agustí-Brisach, C.; Pérez-Rodríguez, M.; Xaviér, C.; Raya, M.C.; Rhouma, A.; Trapero, A. Identification of fungal species associated with branch dieback of olive and resistance of table cultivars to Neofusicoccum mediterraneum and Botryosphaeria dothidea. Plant Dis. 2017, 101, 306-316. [CrossRef] [PubMed]

65. Gramaje, D.; Agustí-Brisach, C.; Pérez-Sierra, A.; Moralejo, E.; Olmo, D.; Mostert, L.; Damm, U.; Armengol, J. Fungal trunk pathogens associated with wood decay of almond trees on Mallorca (Spain). Persoonia Mol. Phylogeny Evol. Fungi 2012, 28, 1-13. [CrossRef] [PubMed]

66. Marsberg, A.; Kemler, M.; Jami, F.; Nagel, J.H.; Postma-Smidt, A.; Naidoo, S.; Wingfield, M.J.; Crous, P.W.; Spatafora, J.W.; Hesse, C.N.; et al. Botryosphaeria dothidea: A latent pathogen of global importance to woody plant health. Mol. Plant Pathol. 2017, 18, 477-488. [CrossRef] [PubMed]

67. Urbez-Torres, J.R. The status of Botryosphaeriaceae species infecting grapevines. In Phytopathologia Mediterranea; University of Florence: Florence, Italy, 2011; Volume 50, pp. 5-45.

68. Slippers, B.; Wingfield, M.J. Botryosphaeriaceae as endophytes and latent pathogens of woody plants: Diversity, ecology and impact. Fungal Biol. Rev. 2007, 21, 90-106. [CrossRef]

69. Gramaje, D.; Armengol, J. Fungal Trunk Pathogens in the Grapevine Propagation Process: Potential Inoculum Sources, Detection, Identification, and Management Strategies. Plant Dis. 2011, 95, 1040-1055. [CrossRef] [PubMed]

70. Fischer, J.; Beckers, S.J.; Yiamsawas, D.; Thines, E.; Landfester, K.; Wurm, F.R. Targeted Drug Delivery in Plants: EnzymeResponsive Lignin Nanocarriers for the Curative Treatment of the Worldwide Grapevine Trunk Disease Esca. Adv. Sci. 2019, 6. [CrossRef]

71. Machado, T.O.; Beckers, S.J.; Fischer, J.; Müller, B.; Sayer, C.; de Araújo, P.H.H.; Landfester, K.; Wurm, F.R. Bio-Based Lignin Nanocarriers Loaded with Fungicides as a Versatile Platform for Drug Delivery in Plants. Biomacromolecules 2020, 21, $2755-2763$. [CrossRef] [PubMed] 